\title{
Electronic Resources
}

Compiled by Anna Appleman

Castro, Jeannie, Richard Guajardo, Matthew Ragucci, and Melissa Randall. "MARC Metamorphosis: Transforming the Way You Look at E-Book Records.” Serials Librarian 76, no. 1-4 (January 2019): 213-19.

Chen, Shih-Chuan. "Exploring the Use of Electronic Resources by Humanities Scholars during the Research Process.” Electronic Library 37, no. 2 (March 2019): 240-54.

Gates, Lynn E. and Rhonda Glazier. “Getting a Handle on Duplicate Ebooks.” Collection Management 44, no. 2-4 (April 2019): 361-78.

Kay, James. "Improving Access to e-Resources for Users at the University of Derby: Enhancing Discovery Systems with Library Plus 2.0.” Insights 32 (2019): 1-12. DOI: http://doi.org/10.1629/uksg.452

Paul, Rachel and Cedar C. Middleton. "Electronic Theses and Dissertations Workflows: Interdepartmental Collaboration at the University of Arkansas Libraries." Collaborative Librarianship 10, no. 4 (October 2018): 282-307. https://digitalcommons.du.edu/collaborativelibrarianship/vol10/iss4/7

Rasuli, Behrooz, Sam Solaimani, and Mehdi Alipour-Hafezi. “Electronic Theses and Dissertations Programs: A Review of the Critical Success Factors.” College \& Research Libraries 80, no. 1 (January 2019): 60-75.

Tracy, Daniel G. “E-Book Use over Time and across Vendors in an Interdisciplinary Field.” Library Resources \& Technical Services 63, no. 2 (April 2019): 143-59. 